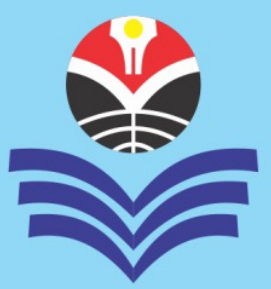

Published every March and September

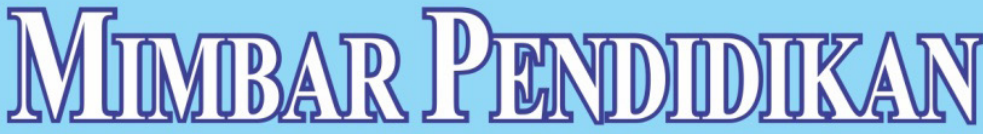

Jurnal Indonesia untuk Kajian Pendidikan

WAKHUDIN

\title{
Menjadi Guru Berkarakter: Meneladani Kepemimpinan Drs. H. Ajat Sudrajat, M.M.Pd. dalam Membangun Sekolah Berkualitas
}

\begin{abstract}
ABSTRAKSI: Artikel ini, dengan menggunakan pendekatan kualitatif dan metode biografi, mengkaji tentang keberhasilan seorang Kepala Sekolah. Hasil kajian menunjukan bahwa Haji Ajat, atau nama lengkapnya Drs. H. (Doktorandus Haji) Ajat Sudrajat, M.M.Pd. (Magister Manajemen Pendidikan), adalah kisah sukses seorang Kepala Sekolah di Kabupaten Kuningan, Jawa Barat, Indonesia. Lebih dari 20 tahun, Haji Ajat menjadi Kepala Sekolah di SMAN (Sekolah Menengah Atas Negeri) yang berbeda-beda. Pada mulanya, Haji Ajat ditugaskan memimpin SMAN Ciniru, sekolah yang jaraknya jauh dari Kuningan Kota; kemudian beliau berpindah ke SMAN Mandirancan, sebuah sekolah di tengah sawah dan di daerah pinggiran; lalu beliau berpindah untuk memimpin SMAN Cilimus, sekolah yang dekat Kota Kuningan; dan beliau berpindah lagi ke SMAN Luragung, sekolah yang dekat dengan daerah Jawa Tengah. Terakhir, Haji Ajat memimpin SMAN III Kuningan, yang berada di tengah Kota Kuningan. Semua sekolah yang dipimpin oleh Haji Ajat selalu berprestasi dalam bidang akademik dan, terutama, sekolah yang ramah lingkungan. Kepala sekolah yang berkarakter dan sukses perlu menjadi teladan bagi siapa pun yang ingin memimpin lembaga pendidikan.

KATA KUNCI: Kepala Sekolah; Sekolah Ramah Lingkungan; Sekolah Berkualitas.
\end{abstract}

ABSTRACT: "Become a Character Teacher: Exemplify the Leadership of Drs. H. Ajat Sudrajat, M.M.Pd. in Building a Quality School". This article, using a qualitative approach and biographical method, examines the success of a Principal. The results of the study show that Haji Ajat, or its full name is Drs. H. (Doktorandus Haji) Ajat Sudrajat, M.M.Pd. (Master of Education Management), is success story of a Principal in Kuningan District, West Java, Indonesia. More than 20 years, Haji Ajat has dedicated to be a Principal in a different SMANs (Public Senior High Schools). At first, Haji Ajat was assigned to lead the SMAN at Ciniru, a school that was far from Kuningan City; then he moved to SMAN at Mandirancan, a school in the middle of rice fields and on the outskirts; then he moved to lead the SMAN at Cilimus, a school near Kuningan City; and he moved again to SMAN at Luragung, a school near to Central Java area. Finally, Haji Ajat leads the SMAN III Kuningan, which is in the center of Kuningan City. All schools led by Haji Ajat always succeed in the academic field and, especially, schools that are environmental friendly. Principals who have character and success need to be role models for anyone who wants to lead an educational institution.

KEY WORD: Principal; Environmentally Friendly Schools; Quality School.

About the Author: Dr. Wakhudin adalah Dosen di Program Studi Pendidikan Guru Sekolah Dasar FKIP UMP (Fakultas Keguruan dan Ilmu Pendidikan, Universitas Muhammadiyah Purwokerto), Jalan Raya Dukuh Waluh, Purwokerto, Banyumas 53182, Jawa Tengah, Indonesia. Alamat emel penulis: wakhudin@gmail.com

Suggested Citation: Wakhudin. (2018). "Menjadi Guru Berkarakter: Meneladani Kepemimpinan Drs. H. Ajat Sudrajat, M.M.Pd. dalam Membangun Sekolah Berkualitas" in MIMBAR PENDIDIKAN: Jurnal Indonesia untuk Kajian Pendidikan, Volume 3(2), September, pp.169-188. Bandung, Indonesia: UPI [Indonesia University of Education] Press, ISSN 2527-3868 (print) and 2503-457X (online).

Article Timeline: Accepted (June 22, 2018); Revised (July 27, 2018); and Published (September 30, 2018). 


\section{PENDAHULUAN}

Tulisan ini bermaksud mendeskripsikan tentang pribadi Drs. H. (Doktorandus Haji) Ajat Sudrajat, M.M.Pd. (Magister Manajemen Pendidikan) secara utuh, beserta seluruh pemikiran dan kiprahnya. Jujur, di samping ingin menulis tentang kebaikannya, penulis juga berupaya mengungkap keburukannya. Tapi pribadi yang satu ini memang betul-betul masagi, yakni nyaris sempurna. Apa yang dia lakukan dan pikirkan lebih banyak dan lebih baik dari apa yang ditulis di sini (Adiwikarta, 1988; Hermawan, 2012; dan Sulasih, 2014).

Lagi pula, menulis kebaikan di zaman sekarang sangat diperlukan. Di saat bangsa Indonesia semakin kehilangan teladan, Drs. H. Ajat Sudrajat, M.M.Pd. mampu menjadi contoh. Yang lebih penting lagi, siapa pun yang akan menjadi Kepala Sekolah di berbagai level satuan pendidikan, pantas berguru kepadanya. Ia adalah pemimpin pendidikan sejati (Hermawan, 2012; dan Sumarno, 2015a).

Mengenal Drs. H. Ajat Sudrajat, M.M.Pd. tak ubahnya seperti mengenal peri. Apa pun yang dia sentuh berubah menjadi menarik hati. Bedanya, peri berkelamin wanita, sedangkan Drs. $\mathrm{H}$. Ajat Sudrajat, M.M.Pd. adalah laki-laki. Peri mengubah sesuatu dalam waktu singkat, sedangkan Drs. H. Ajat Sudrajat, M.M.Pd. mengubah sesuatu melalui proses. Meskipun melalui proses, tetap saja, semua yang dilakukan oleh Drs. H. Ajat Sudrajat, M.M.Pd. termasuk cepat dibandingkan dengan proses jika dilakukan oleh orang lain (Adiwikarta, 1988; Hermawan, 2012; dan Sumarno, 2015a dan 2015b).

Salah satu contohnya sebagai berikut. Setelah Maghrib, Drs. H. Ajat Sudrajat, M.M.Pd. masih berada di sekolah, ditemani oleh Wakil Kepala Sekolah, Haji Suleha, saat masih menjadi Kepala Sekolah di SMAN (Sekolah Menengah Atas Negeri) Mandirancan, Kabupaten Kuningan, Provinsi Jawa Barat, Indonesia. Malam itu, Drs. H. Ajat Sudrajat, M.M.Pd. ingin menuntaskan pembangunan taman. Di tengah perbincangan, mereka menemukan ide, yakni melengkapi taman dengan aneka macam bunga. Begitu ide muncul, saat itu juga, bunga harus didatangkan dan ditanam di taman. Maka, terjadilah dialog berikut ini:

\footnotetext{
"Apa tidak menunggu besok menanam bunganya, Pak Haji?”, kata Pak Uha, panggilan akrab Haji Suleha. “Mengapa harus menunggu besok?”, jawab Haji Ajat (wawancara dengan Responden E, $11 / 7 / 2013)$
}

Maka, dengan berbagai cara, dan dengan usaha yang sungguh-sungguh, setelah menghubungi berbagai tempat yang memungkinkan mendapatkan bunga, Haji Suleha berhasil mendatangkan bunga yang diinginkan. Di malam itu juga, bunga ditanam di taman yang tengah diselesaikan. Maka, tak ubahnya seperti kisah Sangkuriang, SMAN (Sekolah Menengah Atas Negeri) Mandirancan tiba-tiba berubah wajah, dari sekolah kusam menjadi sumringah dalam semalam (Siswoyo, 2016; dan wawancara dengan Responden E, 11/7/2013)

Pola kerja seperti itulah yang selalu dilakukan oleh Drs. H. Ajat Sudrajat, M.M.Pd. Ia selalu meminta para Wakil Kepala Sekolah menemaninya untuk mencari gagasan baru. Begitu ketemu gagasan baru yang bagus, maka gagasan itu langsung dilaksanakan, saat itu juga. Jika gagasannya terpikir malam hari, maka di malam hari itu pula akan dilaksanakan. Jika idenya muncul pagi hari, maka di pagi itu pula gagasannya langsung dilaksanakan. Dia tidak pernah menunda untuk mewujudkan gagasan. Itulah sebabnya, Drs. H. Ajat Sudrajat, M.M.Pd. seperti peri yang selalu mewujudkan impian dalam tempo singkat (Iqbal, 2014; dan wawancara dengan

Responden D, 10/7/2013).

Apakah tidak ada hambatan dalam mewujudkan impian? Ada, selalu ada. 
Tapi bagi Drs. H. Ajat Sudrajat, M.M.Pd., hambatan bukanlah halangan untuk mewujudkan gagasan. Dengan bahasa yang santun dan lembut, dia selalu menantang stafnya. "Memang hambatannya apa?" Katakanlah, uang untuk biaya membangun. Baginya, uang bukanlah hambatan.

Drs. H. Ajat Sudrajat, M.M.Pd. sangat terbiasa menomboki uang pribadi untuk melaksanakan pembangunan sekolah. Kalaupun memerlukan biaya besar, dia tidak risau. Drs. H. Ajat Sudrajat, M.M.Pd. akan mendatangi berbagai instansi yang relevan untuk mensponsori proyek yang dikerjakannya (Yalia, 2014; Sumarno, 2015a dan 2015b; dan wawancara dengan Responden F, 12/7/2013).

Kerja cepat, biasanya, berdampingan dengan ketergesa-gesa dan kualitas yang rendah. Bagi Drs. H. Ajat Sudrajat, M.M.Pd., tidak demikian. Cepat bukan berarti tidak berkualitas. Cepat hanya menyangkut pelaksanaan, sedangkan kualitas tetap harus dijaga. Bahkan, kualitas harus lebih tinggi daripada pembangunan pada umumnya. Ia tak pernah meninggalkan teori. Yang saban hari ia lakukan adalah mewujudkan teori, bukan melulu berkutat pada teori (Sumarno, 2015a dan 2015b; dan Rachbini, 2017).

Lulusan Pendidikan Bahasa Sunda IKIP (Institut Keguruan dan Ilmu Pendidikan) Bandung - kini menjadi UPI (Universitas Pendidikan Indonesia) - tidak hanya mewujudkan teori sesuai disiplin ilmunya. Apa pun teori yang sempat dipelajari dan dibacanya, maka akan ia laksanakan. Agar lebih sempurna, ia memanggil Wakil Kepala Sekolah atau Guru yang mengajarkannya (Widodo, 2011; Karwati et al., 2013; dan wawancara dengan Responden E, 11/7/2013).

Drs. H. Ajat Sudrajat, M.M.Pd. bukanlah tipe pemimpin yang sekadar suka membangun, tanpa melakukan pemeliharaan. Jangan tanya soal kebersihan, sangat bersih. Sepertinya tidak ada sekolah di Indonesia yang dibersihkan dan dipel sebanyak tiga kali dalam sehari. Bahkan, rumah sakit sekalipun dipel dua kali sehari. Tapi sekolah yang dipimpin oleh Drs. H. Ajat Sudrajat, M.M.Pd. harus dipel tiga kali sehari. Maka, terlihat bersih, dan selalu bersinar, meskipun bangunannya tidak baru (Karwati et al., 2013; Sumarno, 2015a dan 2015b; dan wawancara dengan Responden F, 12/7/2013).

Meja dan kursi harus tertata rapi, sesuai peruntukannya. Rapi pun tidak cukup, semua meja harus ditutup taplak yang bersih, sehingga mengesankan ruangan yang berwibawa. Semua ventilasi dipasang gorden, sehingga menambah warna dan pesona. Maka kita dapat membayangkan, sekolah tersebut pasti nyaman. Sebab, semua ditata rapi, dibetulkan setiap fasilitas yang rusak, dilengkapi setiap barang sesuai fungsinya. Lahir adalah utusan batin. Jika bagian luar terlihat rapi, indah, nyaman dipandang, tertib, disiplin, itu berarti batinnya pun mengalami hal yang sama (cf Ahmad, 2017; Sumarno, 2015a; dan wawancara dengan Responden E, 11/7/2013).

Biasanya, orang yang workaholik hanya memikirkan dunia dan melupakan akhirat. Tapi tidak dengan Drs. H. Ajat Sudrajat, M.M.Pd. Justru, kerja tanpa lelahnya itu merupakan ekspresi atas keyakinannya terhadap agama Islam yang dianutnya. Hidup di dunia hanyalah sekali, maka sekali hidup harus berarti. Jangan tanya soal religiusitas pribadinya. Shalat tepat waktu, bertahajud, dan semua rukun Islam telah dijalaninya (Mulyasa, 2007; Asmani, 2012; Sumarno, 2015b; dan wawancara dengan Responden F, 12/7/2013).

Yang bisa diteladani dari religiusitasnya adalah bahwa dia mampu melembagakan tradisi keagamaan menjadi perilaku siswa. Salah satunya adalah Drs. H. Ajat Sudrajat, M.M.Pd. membiasakan siswa datang setengah jam lebih awal dari waktu belajar. Karena siswa harus mulai belajar pukul 7.00 
WIB (Waktu Indonesia Barat), maka mereka harus tiba di sekolah pukul 6.30 WIB.

Setengah jam sebelum belajar digunakan untuk membaca $\mathrm{Al}$-Qur'an. Karena $\mathrm{Al}$ Qur'an merupakan kitab suci, maka siapa pun yang membacanya harus dalam keadaan bersuci (cf Mulyasa, 2007; Asmani, 2012; Mulyadi, 2013; dan Sumarno, 2015a).

Itulah sebabnya, tempat berwudhu di sekolah disediakan dalam jumlah yang cukup. Tapi siswa diajarkan untuk bersuci sejak dari rumah masing-masing, sehingga tak perlu bersuci lagi saat di sekolah. Upaya menyucikan diri bagi siswa dapat memberikan implikasi psikologis religius, mereka tak akan membatalkan wudhunya dengan bersenggolan dengan orang lain yang bukan muhrim (Mulyadi, 2013; Sumarno, 2015b; dan Raharjo, 2016).

Akrab dengan lingkungan hidup merupakan trade mark-nya. Hampir tidak ada ruang terbuka yang lolos tidak ditanami pohon. Pohon apa pun bisa ditanam, yang penting produktif, indah, dan bermanfaat bagi masyarakat di sekitar. Di kebun atau taman yang luas bisa ditanam pohon pangan yang dapat menghasilkan. Di sekitar sekolah, tanaman disesuaikan, agar menimbulkan kesan indah dan meningkatkan marwah dan wibawa sekolah (Mulyasa, 2007; Asmani, 2012; dan Sumarno, 2015a).

Aneka tanaman dan bunga dipasang di setiap ruang publik, baik secara manual ataupun menggunakan sistem hidroponik atau green house. Selain nyaman menjadi tempat berkumpul, terkesan sejuk, membuat semua orang betah tinggal di sekolah untuk belajar. Aneka panel di lingkungan sekolah dipasang pot bunga dan tanaman, sesuai kekhasan ruangan itu. Dari satu gedung ke gedung yang lain dipasang pergola terbuat dari baja ringan, yang menyebabkan orang yang melewatinya tak basah saat hujan dan tak kepanasan saat matahari terik. Besi dan baja tersebut ditanami aneka pohon rambat plus bunga, sehingga mirip lorong yang sangat asyik dilihat mata (Bahri, 2015; dan Sumarno, 2015b).

Membuat candra tentang Drs. H. Ajat Sudrajat, M.M.Pd. seperti mengambil air dari mata air yang tak pernah kering. Ia adalah guru masagi, pendidik yang nyaris sempurna. Sulit mencari titik lemah tentang kepemimpinannya di sekolah. Maka, setiap menjadi Kepala Sekolah di mana pun, sekolah tersebut selalu berprestasi, tidak hanya di tingkat lokal, tapi juga tingkat regional, bahkan di tingkat nasional (Yalia, 2014; dan Sundiawan, 2016a). ${ }^{1}$

Penulisan tentang prestasi dan perilaku terbaik berkaitan dengan kepemimpinannya di bidang pendidikan, diharapkan dapat diteladani siapa pun yang mengembangkan dunia pendidikan, atau siapa pun yang mempelajari education leadership. Dengan jujur, penulis berupaya pula mengungkapkan kekurangannya, jika ditemukan. Karena sulit mencari figur pendidik seperti Drs. H. Ajat Sudrajat, M.M.Pd., maka penulis memberinya sebutan laqob, "Guru Masagi", karena syarat rukun menjadi pemimpin dilakukan nyaris sempurna (Prihatni, 2011; Widodo, 2011; dan Raharjo, 2016).

Perspektif Teoritis. Mendeskripsikan prestasi Drs. H. (Doktorandus Haji) Ajat Sudrajat, M.M.Pd. (Magister Manajemen Pendidikan) sesungguhnya sedang menjelaskan tentang teori pendidikan karakter dan kepemimpinan yang efektif dalam kepemimpinan pendidikan (education leadership). Drs. H. Ajat Sudrajat, M.M.Pd. merupakan pribadi yang mampu menggerakkan seluruh sumber daya yang ada, termasuk sumber daya manusia untuk bergerak sesuai dengan tujuan yang diinginkan (Rohiat, 2008; dan Suhartini, 2015).

\footnotetext{
${ }^{1}$ Lihat kembali, misalnya, "Drs. H. Sudrajat, M.M.Pd. Nominasi Kategori Pembina Lingkungan" dalam KALPATARU. Jakarta: 22 Juni 2016. Tersedia secara online juga di: https://kalpataru2016.wordpress.com/2016/06/22/ d-02-drs-h-sudrajat-m-m-pd-nominasi-kategori-pembinalingkungan [diakses di Purwokerto, Jawa Tengah, Indonesia: 27 Desember 2017].
} 
Sebagaimana dikemukakan bahwa kepemimpinan adalah proses mempengaruhi orang, baik individu maupun kelompok. Pemimpin adalah seseorang yang aktif membuat rencana, mengkoordinasikan, melakukan percobaan, dan memimpin pekerjaan untuk mencapai tujuan bersama. Karakteristik pemimpin didasarkan pada prinsip belajar seumur hidup, berorientasi pada pelayanan, dan membawa energi positif (Danim, 2010; dan Eko, 2018).

Di samping itu, kepemimpinan efektif yang dijalankan oleh Drs. H. Ajat Sudrajat, M.M.Pd. sesungguhnya merupakan praktek pendidikan karakter. Semakin kuat karakter pemimpin, semakin efektif dalam memimpin. Dapat dikatakan bahwa Drs. H. Ajat Sudrajat, M.M.Pd. mampu melaksanakan 18 karakter baik, yang menyebabkan dia menjadi pemimpin yang disegani. Ke-18 karakter baik tersebut adalah: (1) religius; (2) jujur; (3) toleransi; (4) disiplin; (5) kerja keras; (6) kreatif; (7) mandiri; (8) demokratis; (9) rasa ingin tahu; (10) semangat kebangsaan; (11) cinta tanah air; (12) menghargai prestasi; (13) bersahabat/komuniktif; (14) cinta damai; (15) gemar membaca; (16) peduli lingkungan; (17) peduli sosial; dan (18) tanggung jawab ( $c f$ Lickona, 1991; Mu'in, 2011; dan Mustakim, 2011).

Dalam konteks ini, Abraham Lincoln, sebagaimana dikutip dalam Luno (2016) pernah mengemukakan, sebagai berikut:

Nearly all men can stand adversity, but if you want to test a man's character, give him power (dalam Luno, 2016).

\section{Artinya:}

Hampir semua orang teruji dengan kesusahan, tapi kalau mau menguji karakternya, berikan dia kekuasaan.

Sementara itu, Helen Keller, sebagaimana dikutip oleh Henrik Edberg (2010) dan A. Syamsu Rizal et al. (2016), berpendapat sebagai berikut:
Character cannot be developed in ease and quiet. Only through experience of trial and suffering can the soul be strengthened, ambition inspired, and success achieved (dalam Edberg, 2010).

\section{Artinya:}

Karakter tidak dapat dikembangkan dengan mudah dan baik. Hanya melalui pengalaman dengan mencoba dan derita membuat jiwa menjadi kuat, terinspirasi ambisi, dan mencapai sukses (dalam Rizal et al., 2016:19).

Sedangkan John Holt, sebagaimana dikutip juga dalam A. Syamsu Rizal et al. (2016), mengungkapkan bahwa the true test of character is not how much we know how to do, but how we behave when we don't know what to do atau "ujian yang benar dari karakter bukan berapa banyak kita mengetahui bagaimana berbuat, tapi bagaimana kita menyikapi ketika kita tidak mengetahui apa yang dilakukan" (dalam Rizal et al., 2016).

Demikian juga Anne Frank, sebagaimana dikutip oleh Stef Riko Saputra (2011), dimana ia mengemukakan bahwa the final forming of a person's character lies in their own hands atau "pembentukan akhir dari karakter seseorang, terletak di tangan mereka sendiri" (dalam Saputra, 2011). Dalam konteks ini juga, Herbert Spencer (1820-1903), dalam Brian Holmes (2002), menambahkan bahwa education has for its object the formation of character atau "pendidikan memiliki tujuannya untuk pembentukan karakter" (dalam Holmes, 2002).

Menjelaskan tentang kepemimpinan pendidikan, Aminuddin Syam (2012) mengatakan bahwa sebelum otonomi pendidikan diberlakukan, kepemimpinan pendidikan yang dilaksanakan saat itu adalah kepemimpinan pendidikan sentralistik (Syam, 2012:151). Kepemimpinan pendidikan sentralistik menggunakan strategi input-output dan macro oriented. Dalam strategi input-output, jika semua input pendidikan dipenuhi 
dalam pengelolaan pendidikan, maka pendidikan menghasilkan pendidikan yang bermutu. Sedangkan menurut strategi macro oriented, pengelolaan pendidikan diatur oleh jajaran pendidikan ditingkat pusat, manakala kepemimpinan pendidikan di tingkat sekolah hanya melaksanakan semua ketentuan yang ditetapkan di tingkat pusat, dengan cara demikian diharapkan dapat diperoleh peningkatan mutu pendidikan ( $c f$ Syam, 2012; dan Sulaeman, 2018).

Setelah diberlakukan otonomi daerah, termasuk otonomi pendidikan, dengan Peraturan Pemerintah Nomor 25 Tahun 2000, maka kepemimpinan pendidikan di sekolah harus menyesuaikan pula dengan peraturan tersebut. Kepemimpinan pendidikan yang cocok di era otonomi pendidikan itu adalah kepemimpinan yang inovatif. Kepemimpinan yang inovatif adalah kepemimpinan yang mampu melakukan perubahan atau inovasi dalam institusi pendidikan (Gunawan, 2000; dan Jalal \& Supriadi eds., 2001).

Kepemimpinan pendidikan yang inovatif di era otonomi pendidikan ini sangat dibutuhkan, karena: (1) corak hidup dan fungsi manusia berubah dengan pertambahan usia; serta (2) dunia dan kehidupan manusia mengalami perubahan dari waktu ke waktu. Bahkan pemikiran modern mengatakan bahwa kepemimpinan pendidikan tidak hanya mampu menyesuaikan diri pada dunia kehidupan yang berubah, tetapi juga berperan dalam menciptakan dan pengendalian perubahan itu (Syam, 2012:151; dan Rusdiana, 2014).

Muhammad Noer (2018) mengemukakan bahwa pemimpin (leader) adalah orang yang mengayomi timnya. Dia ikut berada di depan dan bekerja bersama-sama dengan timnya. Pemimpin berbeda dengan manajer. Manajer terkesan banyak jeleknya, suka memerintah, mengatur anak buah, dan tak jarang disertai kemarahan ketika hasil yang diharapkan tidak tercapai. Sementara leader memiliki citra yang jauh lebih baik.
Leader dianggap orang yang mengerti betul kebutuhan semua orang ( $c f$ Andriansyah, 2015; dan Noer, 2018:21).

Sepintas, pendapat Muhammad Noer (2018) tersebut ada benarnya. Namun pendapat tersebut juga bisa memiliki kesalahan fatal. Benar, karena masih banyak manajer yang memang belum melakukan tugasnya dengan baik, sehingga mendapat penilaian negatif. Bisa jadi, ini sebagai bentuk ketidakpuasan yang dirasakan karyawan terhadap manajer mereka masingmasing, sehingga tercermin dalam definisi yang mereka sampaikan. Salah, karena penjelasan di atas menggambarkan seolaholah hal yang jelek ada pada manajer, dan yang baik ada pada leader. Padahal, baik manajer maupun leader pada dasarnya memiliki konotasi yang baik ( $c f$ Berlian, 2012; dan Noer, 2018).

Diungkapkan bahwa leader is a person who leads or commands a group, organization, or country atau "leader adalah seseorang yang memimpin atau memerintah sebuah kelompok, organisasi, atau negara". Jika kita lihat dari definisi di atas, ada kemiripan antara manajer dan leader. Baik manajer maupun leader samasama bertugas untuk sekelompok orang tertentu, yang menjadi bagian dari timnya. Sedangkan sang manajer atau leader adalah orang yang bertanggung jawab, mengelola, memimpin, atau memerintah sekelompok orang tersebut. Leaders are people who do the right things; managers are people who do things right atau "Para leaders adalah mereka yang melakukan sesuatu dengan benar; para manajer adalah mereka yang benar melakukan sesuatu" (Noer, 2018:25).

Abd Haris (2013) mengemukakan bahwa memimpin berarti mempengaruhi bawahan agar mereka mau bekerja dengan baik, sesuai dengan prosedur dan metode kerja yang telah ditetapkan. Kepemimpinan juga dapat diartikan sebagai proses kegiatan seseorang untuk mempengaruhi, menggerakan, dan mengkoordinasikan 
individu atau kelompok agar terwujud hubungan kerja sama dalam upaya mencapai tujuan yang telah ditetapkan. Seringkali kepemimpinan disamakan dengan pemimpin, padahal keduanya memiliki perbedaan makna. Pemimpin merupakan seseorang yang memiliki tugas memimpin, sementara kepemimpinan merupakan bakat atau sifat yang harus dimiliki oleh seorang pemimpin (Haris, 2013:14; dan Wahed, 2016).

Sedangkan kepemimpinan pendidikan merupakan proses mempengaruhi, menggerakan, dan mengkoordinasikan individu dalam organisasi/lembaga pendidikan untuk mencapai tujuan pendidikan. Seperti halnya kepemimpinan Kepala Sekolah, maka ia memiliki peran dalam mempengaruhi, mendorong, membimbing, mengarahkan, dan menggerakan guru, staf, siswa, orang tua siswa, dan pihak lain yang terkait untuk beraktivitas/berperan serta guna mencapai tujuan yang telah ditetapkan (Mulyadi, 2010; dan Haris, 2013:16).

\section{METODE}

Artikel ini merupakan hasil penelitian yang menggunakan pendekatan kualitatif dengan metode biografi. Metode biografi merupakan salah satu tradisi kualitatif (Creswell, 1998:63; dan Safari, 2013). Studi ini juga merupakan salah satu dari lima tradisi riset kualitatif. Lima tradisi kualitatif tersebut adalah biografi, fenomenologi, grounded theory, etnografi, dan studi kasus (Creswell, 1998:65). Penelitian ini disebut juga dengan naturalistic inquiry (Lincoln \& Guba, 1985); qualitative inquiry (Creswell, 1998); atau penelitian alamiah atau naturalistic (Moleong, 2004).

Beberapa teknik penelitian digunakan, yaitu dengan melakukan observasi dengan mengunjungi beberapa kali SMA (Sekolah Menengah Atas) yang pernah dipimpin oleh Drs. H. (Doktorandus Haji) Ajat Sudrajat, M.M.Pd. (Magister Manajemen Pendidikan) di Kabupaten Kuningan,
Jawa Barat, seperti SMA Negeri Ciniru, SMA Negeri Mandirancan, SMA Negeri Cilimus, SMA Negeri Luragung, dan SMA Negeri III Kuningan. Di samping itu, teknik wawancara digunakan untuk menginterviu Drs. H. Ajat Sudrajat, M.M.Pd., serta para mantan Wakil Kepala Sekolah dari semua sekolah yang pernah dipimpinnya. Wawancara dilakukan secara bertahap, dalam beberapa sesi. Pertama dilakukan pada tahun 2013, dan terakhir dilakukan dari tanggal 22 hingga 27 Maret 2017 di SMA Negeri III Kuningan (Spradley, 1980; Yin, 2004; dan Hasanah, 2016).

Sejumlah dokumen sekolah, buku, foto, dan berbagai slide lainnya digunakan untuk melakukan penelitian ini, sehingga diperoleh data yang valid dan dapat dipertanggungjawabkan. Setiap perwakilan sekolah yang pernah dipimpinnya, dengan semangat menyerahkan berbagai dokumen penting tentang capaian (achievement) yang diraih oleh Drs. H. Ajat Sudrajat, M.M.Pd. selama memimpin. Bagi mereka, mengenang Drs. H. Ajat Sudrajat, M.M.Pd. dirasakan sebagai mengenang keberhasilan (Spradley, 1980; Yin, 2004; Hasanah, 2016; dan wawancara dengan Responden E, 11/7/2013).

\section{HASIL PENELITIAN DAN PEMBAHASAN}

Drs. H. (Doktorandus Haji) Ajat Sudrajat, M.M.Pd. (Magister Manajemen Pendidikan) adalah sosok tiga "dewa" yang menyatu dalam dirinya, yakni: Batara Brahma, Batara Wisnu, dan Batara Siwa. Batara Brahma, menurut khasanah perwayangan Jawa, adalah dewa pencipta segala sesuatu di marcapada. Apa pun yang dicipta selalu jadi. Tidak ada penghalang apa pun. Sementara Wisnu adalah dewa yang memelihara dan menjaga semua ciptaan Dewa Brahma. Sedangkan Siwa adalah dewa perusak, merusak ciptaan Brahma. Namun tiga dewa inilah yang merupakan siklus kehidupan. Mulai dari diciptakan, 
dipelihara, rusak, kembali diciptakan, dipelihara, rusak, dan seterusnya (Mulyono, 1989; Margana, 2001; dan wawancara dengan Responden E, 11/7/2013).

Haji Ajat, begitu panggilan sehari-hari Drs. H. Ajat Sudrajat, M.M.Pd., sangat piawai mencipta sesuatu yang baru, sangat rajin memelihara dan merawat kebaikan, dan sangat bersemangat merusak dan menghancurkan kekumuhan, kemalasan, dan ketidakbaikan. Haji Ajat adalah "dewa yang mangejawantah" mengabdikan dirinya, setidaknya di lima sekolah di Sekolah Menengah Atas (SMA) Kuningan, Jawa Barat. Apa pun yang "disentuh tangannya" selalu berubah. Seperti kisah Sunan Kalijaga, yang mampu "mengubah" buah kolang-kaling atau cangkaleng menjadi emas dalam waktu seketika (Isnaeni, 2015; dan wawancara dengan Responden B, 4/7/2013).

Siapa pun yang mengenal Haji Ajat akan membuatnya "jatuh cinta" kepadanya. Tidak saja kepada pribadinya, melainkan juga kepada budi bahasa, perilaku, kreasi, serta inovasinya. Memang tak banyak yang bisa dikorek dari pribadinya, jika seseorang bertemu muka dengannya. Sebab, ia adalah pribadi low profile, rendah hati, dan tidak akan pernah menceritakan prestasi yang pernah diraihnya. Ia "tak tahu diri", tak tahu bahwa dirinya berprestasi. Kalau ingin tahu tentang Haji Ajat, maka temuilah para mantan Wakil Kepala Sekolah yang pernah membantunya. Mereka dengan bersemangat akan menceritakan bagaimana kinerja Haji Ajat yang hidupnya "berlari dan terus berlari, tapi dijalani dengan senang hati" (Sinamo, 2005; wawancara dengan Responden A, 3/7/2013; dan wawancara dengan Responden C, 5/7/2013).

Salah seorang yang sangat aktif dan setia kepadanya adalah Pak Uha atau Haji Suleha itu. Demikian juga semua Wakil Kepala Sekolah yang pernah mendampinginya. Semua merasakan hal yang sama dengan yang dirasakan Pak Uha. Haji Ajat adalah pribadi yang luar biasa. Beberapa ciri khas Haji Ajat adalah pertama, ia tak pernah berhenti berinovasi dan berkreasi.

Sebagaimana dinyatakan oleh para mantan Wakil Kepala Sekolahnya, sebagai berikut:

Ya, nyaris 24 jam, Haji Ajat selalu berpikir sesuatu yang baru. Jika satu pekerjaan selesai, dia mengerjakan pekerjaan berikutnya tanpa berhenti. Baginya, waktu 24 jam seperti tidak cukup (wawancara dengan Responden E, 11/7/2013)

Jika Allah tidak menganugerahkan rasa lelah dan rasa kantuk kepada manusia, niscaya Haji Ajat memanfaatkan semua waktunya untuk membangun, mencipta, berkreasi, berinovasi, melakukan perbaikan, memugar, melakukan pengadaan, dan seterusnya. Itulah sebabnya, ia harus beristirahat meskipun pulang ke rumah saat malam sudah larut. Dia tidak peduli tentang jam kerja Pegawai Negeri Sipil, yang bekerja sekian jam. Baginya, semua waktu digunakan untuk mengerjakan semua yang menjadi tanggung jawabnya (wawancara dengan Responden F, 12/7/2013)

Meskipun pulang larut malam, tapi saat Subuh, dia sudah berangkat kembali ke sekolah. Meneruskan pekerjaan yang belum selesai. Persis seperti "Sangkuriang” yang berhasil menciptakan kapal dalam waktu semalam. Dalam beberapa kasus, ia "memaksa" Wakil Kepala Sekolah dan stafnya untuk bekerja lembur hingga larut malam, sampai pekerjaan tuntas. Di SMA Negeri 1 Mandirancan, misalnya, Haji Ajat berhasil "memaksa" anak buahnya mengubah comberan menjadi taman bunga dalam semalam, saat sekolahnya akan mengikuti lomba lingkungan hidup. Anehnya, anak buahnya tidak mengeluh, malah merasa gembira, bahkan bangga selamanya, karena dengan karyanya itu SMAN 1 Mandirancan itu meraih Juara 1 Nasional dalam bidang lingkungan (wawancara dengan Responden D, 10/7/2013).

Bagaimana SMA Negeri 1 Mandirancan tidak juara, SMA yang letaknya di pinggir sawah dan agak jauh dari perumahan penduduk ini tadinya termasuk sekolah yang bukan favorit. Tapi, kedatangan Haji Ajat benar-benar menjadi berkah. Apa pun yang 
"disentuhnya" kemudian menjadi hidup. Halaman sekolah "disentuh" berubah menjadi lapangan bola basket. Karuan, semangat siswa berolah raga bangkit. Lapangan basket menjadi kebanggaan peserta didik. Apalagi, lapangan basket yang dibangun di tengah sekolah dikurung dengan kawat secara memutar dan ditutup dengan aneka pepohonan rambat yang indah. Terasa nyaman, sejuk, hijau, sehat, lapang, membanggakan, dan itulah "ikon" sekolah yang selalu jadi kenangan siswa sepanjang masa.

Belum lagi, satu gedung sekolah dengan gedung lainnya dihubungkan dengan gondola yang membentuk lorong, yang dapat menahan terik sinar matahari. Maka siapa pun yang berjalan dari satu kelas ke kelas yang lain, atau dari satu gedung ke gedung yang lain, tidak akan tersentuh air saat hujan atau tidak kepanasan saat matahari menyengat. Semua lorong ini juga memiliki ciri yang khas, yaitu ditumbuhi pepohonan, khususnya pohon rambat yang mengikuti lenturnya lorong itu. Halaman sekolah yang biasanya mubazir dibuat menjadi taman bunga. Tak tanggungtanggung menjadi taman anggrek. Tanah sisanya dibuat menjadi kolam ikan. Siapa pun boleh memancingnya. Ikannya banyak. Tapi karena indah dipandang mata, pada umumnya siswa dan guru lebih suka memelihara ikan itu daripada mengkonsumsinya (wawancara dengan Responden E, 11/7/2013).

Kedua, apa pun sekolah yang dipimpin oleh Haji Ajat, panggilan akrab bagi Drs. H. (Doktorandus Haji) Ajat Sudrajat, M.M.Pd. (Magister Manajemen Pendidikan), maka yang tadinya pabalatak (berantakan) berubah menjadi rapi, ramah lingkungan, indah, dan enak dilihat. Saksikan, misalnya, SMAN (Sekolah Menengah Atas Negeri) Cilimus, yang berada di kawasan wisata Sangkanhurip, Kuningan, Jawa Barat, dulunya terlihat kumuh. Dari jalan, tak ada kesan bahwa bangunan itu merupakan sekolah. Tapi saat Haji Ajat memimpin SMAN itu, maka segalanya berubah. Batas sekolah dengan kampung segera ditandai dengan tembok keliling, sehingga keluarmasuknya guru dan siswa dapat dikontrol secara baik. Sebelum orang lain datang,
Haji Ajat sudah tiba di depan pintu gerbang, menyambut setiap siswa, dan guru yang datang dengan ramah dan dengan senyum yang tulus (Sutikno, 2015; dan wawancara dengan Responden G, 22/3/2017).

Berikut adalah kesaksian dan pernyataan dari para mantan Wakil Kepala Sekolah tentang pribadi dan prestasi Haji Ajat dalam memimpin sekolah:

Halaman yang kumuh disulap sebagai taman. Penjaga sekolah difungsikan maksimal. Memang terpaksa harus merelokasi pedagang yang mangkal di depan sekolah. Namun, pedagangnya pun tahu diri, merasa tidak pantas berada di sekolah yang tibatiba terlihat megah. Kondisi warungnya tak cocok dengan wajah sekolah yang terlihat sumringah. Siapa pun tak akan ada yang melihat tembok dan kayu yang tidak dicat, bahkan saat terlihat kusam sedikit, tembok itu segera dicat ulang agar terlihat menggairahkan (wawancara dengan Responden I, 22/3/2017).

Haji Ajat datang berarti sampah hilang. Jangankan sampah, ruang kelas pun harus dipel setiap waktu. Bahkan lebih bersih dari rumah sakit, sebab sekolah dipel tiga kali sehari. Sepertinya, tak boleh ada sebutir debu pun menempel di lantai. Juga tak boleh ada secuil sampah pun di lingkungan sekolah. Semua harus "clean" dan "clear". Haji Ajat sendiri ikut melakukannya, membangun, memelihara, mengecat, mengepel, dan seterusnya. Tentu ia dibantu para Wakil Kepala Sekolah, Guru, dan tenaga pendidik lainnya. Semua orang bergerak, berpikir, bekerja dan bekerja seperti tanpa henti (wawancara dengan Responden G, 22/3/2017).

Begitu selesai satu pekerjaan, Haji Ajat bertanya kepada para Wakilnya, "Apa lagi yang harus dikerjakan?" Begitu dijawab A atau B, maka itulah yang harus dikerjakan saat itu. Tidak ada kata menunda. Kalau diperlukan saat itu, maka dilakukanlah saat itu juga. Kalau harus diselesaikan sampai malam, ya dikerjakan sampai malam. Kalau harus ditunda, besoknya dikerjakan lagi di pagi hari sampai tuntas. Tak ada kamus menunda pekerjaan, apalagi yang menyangkut hajat hidup orang banyak. Ada 
gagasan, berarti ada dalam kenyataan. Itulah Haji Ajat (wawancara dengan Responden H, 27/7/2013).

Jangan tanya kepada Wakil Kepala Sekolah soal capek atau tidak. Tentu capek, sangat capek, dan selalu tegang. Wakil Kepala Sekolah harus mengikuti irama Kepala Sekolah, yang sepertinya "tidak punya udel" ini. Sebelum matahari bersinar, pada umumnya, mereka sudah berada di sekolah, hingga matahari sudah terbenam pun, mereka masih berada di tempat belajar itu. Bahkan, di hari Minggu yang mestinya libur sekalipun, Wakil Kepala Sekolah kadang bersama para Guru tetap berada di sekolah. Memang untuk bersantai, sekadar makan nasi liwet bersama, dengan mengajak keluarga. Namun, di tengah santainya bersama Pak Ajat, semua harus berpikir, dan kemudian dilanjutkan dengan bekerja keras (wawancara dengan Responden G, 22/3/2017).

Apakah para Wakil Kepala Sekolah yang mendampingi Haji Ajat sakit hati kepadanya? Inilah istimewanya. Tidak. Mereka seperti terhipnotis. Mereka pada umumnya justru terkagum-kagum dengan apa yang dilakukannya. Mereka tak pernah membayangkan bahwa dirinya mampu melakukan banyak aktivitas besar, yang tak mungkin dilakukannya tanpa ada Pak Ajat. Praktis, Haji Ajat hanya memberikan stimulus, sedangkan yang melaksanakannya para Wakil Kepala Sekolah bersama Guru, tenaga kependidikan, dan para peserta didik. Dengan Pak Ajat, semua bergerak, semua mendapatkan peran, semua aspirasi ditampung dan dilaksanakan (wawancara dengan Responden H, 27/7/2013).

Wakil Kepala Sekolah, pada umumnya, seperti mimpi. Tiba-tiba mereka merasa bisa mengubah halaman sekolah yang kumuh menjadi kolam ikan yang indah, dengan tumbuhan ganggang di tengahnya yang disinggahi ikan warna-warni. Mereka tidak membayangkan sebelumnya ruang kelas yang tadinya terdiri atas tegel pecah, tibatiba berubah menjadi keramik yang bersih mengkilat. Wakil Kepala Sekolah sering terperanjat sendiri, tadinya hidup santai tanpa tujuan yang jelas, tiba-tiba memiliki program kerja konkret yang harus dikerjakan sekarang juga. Mereka juga terkaget-kaget sendiri, saat sekolah yang dipimpinnya, tadinya masuk sekolah biasa, tiba-tiba menjadi sekolah favorit (wawancara dengan Responden I, 22/3/2017).

Ketiga, ciri khas yang melekat erat dengan Haji Ajat, atau nama lengkapnya Drs. H. (Doktorandus Haji) Ajat Sudrajat, M.M.Pd. (Magister Manajemen Pendidikan), adalah kecintaan kepada lingkungan. Pembangunan apa pun yang dilakukannya tidak pernah dipisahkan dari perhatian untuk memelihara dan menumbuhsuburkan lingkungan. Di mana pun Haji Ajat memimpin, maka sekolah tersebut otomatis berubah menjadi sekolah yang ramah lingkungan. Saat Haji Ajat harus menjadi Kepala Sekolah di SMAN (Sekolah Menengah Atas Negeri) Luragung, Kuningan, Jawa Barat, misalnya, sebagian orang terperanjat, karena menyangka Haji Ajat dibuang ke tempat yang jauh. Amat sangat disayangkan, Kepala Sekolah dengan segunung prestasi ini harus memimpin sekolah yang jauh dari kota dan berada di pelosok yang jarang dilewati, selain sebagai jalan alternatif saat pemudik pulang ke Jawa Tengah dari Jawa Barat (Mulyasa, 2007; Sutikno, 2015; dan wawancara dengan Responden J, 23/3/2017).

Berikut adalah kesaksian dan pernyataan dari para mantan Wakil Kepala Sekolah tentang pribadi dan prestasi Haji Ajat dalam memimpin sekolah:

Lagi-lagi, Haji Ajat adalah Pak Ajat. Dia tak pernah kalah dan menyerah. Memimpin sekolah yang tadinya tak terkenal pun dilakukan sepenuh hati dan sepenuh waktu. Semuanya seperti mutlak, sekolah dan lingkunga harus bersih, ruang belajar dipel minimal dua kali sehari, tak boleh kusam, semua mengkilat, tak boleh ada lahan kosong yang mubazir, lingkungan harus indah dan menyenangkan. Wakil Kepala Sekolah, para Guru, dan tenaga kependidikan harus "berlari", berdisiplin yang super super super ketat (wawancara dengan Responden K, 24/3/2017).

Jangan lupa, SMA Negeri 1 Luragung memiliki luas tanah 14,000 meter, sekolah 
terluas di Kuningan. Tanah seluas apa pun, tak boleh mubazir. Maka, Haji Ajat menggali lubang tanah di sana sini, membangun tempat penampungan air, memasang pipa air sebagai air resapan yang dapat mengondisikan kesuburan tanah. Semua tanah seluas itu ditanami aneka sayuran dan buah-buahan. Seluas apa pun, batas sekolah dengan tanah masyarakat disekat dengan tembok. Semua SATPAM (Satuan Pengamanan) difungsikan dengan baik untuk mengatur kendaraan siswa, guru, dan tamu yang datang; menjaga keamanan; dan menjaga harta sekolah. Mereka makmur, karena setiap saat bisa memanen sayur dan buah yang dibutuhkan keluarga (wawancara dengan Responden J, 23/3/2017).

Haji Ajat bukanlah olahragawan, meskipun sangat suka bermain bola di saat muda. Tapi jangan tanya kepeduliannya terhadap aktivitas siswa. Maka, dibangunlah aneka lapangan untuk berolah raga. Bola basket seperti lagu wajib. Bola voley juga seperti keharusan. Lapangan sepak bola juga sebuah keniscayaan. Maka, apa pun hobi siswa SMA Negeri 1 Luragung dipenuhi, asalkan mereka berlatih secara serius dan antusias. Maka, jangan pernah menantang atlet asal SMA Negeri 1 Luragung saat Haji Ajat memimpin, semua akan dimenangkannya.

Haji Ajat juga bukan seniman. Tapi perhatiannya terhadap seni juga tak usah diragukan. Siswa SMA Negeri 1 Luragung dimanjakan dengan aneka macam peralatan seni. Mereka yang gemar bermusik, sekolah menyiapkan beberapa perangkat musik secara lengkap dengan kualitas terbaik. Siswa dilatih bermain gitar, piano, gendang, dan semua alat musik. Maka, SMA 1 Luragung mendadak panen artis. Apa pun kegiatannya, bermusik menjadi tradisi baru di SMA ini. Bahkan setiap Minggu pagi, siswa SMA 1 Luragung menghibur pengunjung "Car Free Day” di Kuningan. Bermusik akhirnya menjadi ciri khas SMA Negeri 1 Luragung.

Tak hanya musik modern, Haji Ajat juga bersemangat melatih siswa memainkan musik tradisional. Dia membuat grup pemain "karinding". Meskipun saat itu "karinding" belum begitu dikenal, dengan permainan kolosal dan dimainkan secara serius dan semangat, seni ber- "karinding" dapat membuat bulu kuduk merinding. Indah, menggetarkan. Haji Ajat juga membentuk grup "rampak kendang”. Memang tidak romantis kesenian ini, tapi terasa "sigrak", semangat, menggugah rasa, dan sangat meriah. Apa pun pertemuannya, jika dimeriahkan dengan "rampak kendang” SMA Negeri 1 Luragung, terasa megah dan meriah. Inilah ciri khas "rampak kendang”. Dengan "rampak kendang”, Haji Ajat berhasil membangkitkan gairah masyarakat sekolah SMA 1 Luragung. Maka jangan heran, sekolah yang sempat lesu peminat, tiba-tiba pendaftarnya membludak (wawancara dengan Responden K, 24/3/2017).

Keempat, ciri lain Haji Ajat, nama lengkapnya Drs. H. (Doktorandus Haji) Ajat Sudrajat, M.M.Pd. (Magister Manajemen Pendidikan), adalah religius. Secara fisik, dia sangat menjaga kebersihan, baik badan maupun lingkungan. Tapi secara rohani, Haji Ajat juga menjaganya amat sangat, sangat, dan sangat ketat. Meskipun sekolah yang dipimpinnya SMA (Sekolah Menengah Atas) Negeri, namun ia memperlakukannya seperti santri. Semua siswa Muslim harus dapat membaca dan menulis Al-Qur'an. Maka sebelum jam sekolah dimulai, semua siswa harus sudah di kelas. Mereka harus membaca Al-Qur'an terlebih dahulu secara tartil. Membaca Al-Qur'an haruslah suci, semua siswa harus berwudhu sebelum menyentuh mushaf $A l-Q u r$ 'an. Kalau tidak bersuci di sekolah, siswa harus mengambil air wudhu di rumah masing-masing, sehingga di sekolah tidak perlu berebut kran untuk berwudhu (Sahlan, 2010; dan wawancara dengan Responden A, 3/7/2013).

Berikut adalah kesaksian dan pernyataan dari para mantan Wakil Kepala Sekolah tentang pribadi dan prestasi Haji Ajat dalam memimpin sekolah:

Dalam keadaan bersuci, siswa tidak akan melakukan perbuatan asusila, saat berangkat ke sekolah. Saat di angkutan kota, misalnya, siswa laki-laki berusaha menghindar bersenggolan dengan perempuan. Demikian pula siswa putri, mereka melakukan sikap yang sama agar kesuciannya terpelihara. Ternyata, membaca Al-Qur'an di sekolah berimplikasi terhadap sikap siswa di jalan. Kalaupun siswa laki-laki berboncengan 
motor dengan siswa perempuan, mereka tidak main tempel layaknya suami-istri. Dengan berwudhu, hubungan siswa-siswi relatif terjaga. Semua sekolah yang dipimpin oleh Haji Ajat harus melakukan kegiatan seperti ini, pun dengan SMA Negeri III Kuningan, yang termasuk sekolah favorit. Biar favorit secara akademik, SMA ini juga harus favorit secara spiritual, termasuk harus dibersihkan lebih licin dari rumah sakit, karena dipel tiga kali sehari (wawancara dengan Responden C, 5/7/2013).

Nasib Haji Ajat sepertinya "tidak pernah beruntung". Dia selalu menjadi "Kepala Sekolah buangan”. Pertama kali menjadi Kepala Sekolah, ia ditempatkan untuk memimpin SMA Negeri Ciniru, sebuah SMA di daerah yang paling terpencil di Kuningan. Jalan menuju SMA ini harus melalui jalan yang tak mulus. Tapi sejak awal, Haji Ajat adalah pribadi yang super disiplin. Sebelum matahari terbit, dia sudah berada di sekolah itu, sampai matahari sudah terbenam lama. Semua dilakukan sesuai dengan langgam hidupnya. Meskipun SMA Ciniru awalnya disebut sebagai SMA kampung, di tangan Haji Ajat berubah menjadi sekolah yang mampu memenangi berbagai jenis olah raga dan kesenian. Lapangan basket mampu mengangkat harkat dan martabat serta marwah siswa, sehingga mereka tidak lagi minder di hadapan sekolah lain (wawancara dengan Responden B, 4/7/2013).

Haji Ajat, nama lengkapnya Drs. H. (Doktorandus Haji) Ajat Sudrajat, M.M.Pd. (Magister Manajemen Pendidikan), adalah pribadi masagi, nyaris sempurna. Maka, ciri khas kelima, dia orang yang tidak pernah pusing dengan dana. Berapa pun dana yang dibutuhkan untuk membangun sekolah yang dipimpinnya, dia tidak memusingkannya. Kemampuannya berkomunikasi, baik secara horisontal maupun vertikal, dilakukannya secara elok dan berhasil. Dia mampu melakukan pendekatan kepada pemerintah untuk mendapatkan haknya dalam membangun sekolah yang dipimpinnya. Tak berhasil, dia membangkitkan semangat siswa dan guru untuk melakukan patungan membangun apa pun yang diperlukannya.
Tak jarang, siswa harus membawa pohon, benih, aneka macam tanaman, dan sebagainya. Dari tanaman yang dipelihara baik, sekolah yang dipimpin oleh Haji Ajat menghasilkan aneka sayuran dan buah-buahan, serta aneka bunga. Minimal dikonsumsi oleh warga sekolah, lebih jauh bahkan dapat menghasilkan uang (Mulyasa, 2007; Sutikno, 2015; dan wawancara dengan Responden D, 10/7/2013).

Berikut adalah kesaksian dan pernyataan dari para mantan Wakil Kepala Sekolah tentang pribadi dan prestasi Haji Ajat dalam memimpin sekolah:

Berbagai macam kerja sama yang
dilakukan dengan klien, baik menyangkut
kesenian maupun kerja sama yang bersifat
komersial, juga kerap menghasilkan uang
yang dapat digunakan untuk membangun
sekolah yang dipimpinnya. Berbagai
prestasi yang dicetaknya kerap mampu
memenangi aneka macam lomba. Uang yang
dihasilkannya dimanfaatkan secara produktif,
sehingga menghasilkan prestasi yang juga
menghasilkan uang (wawancara dengan
Responden E, 11/7/2013).

Yang jarang dilakukan sekolah lain, Haji Ajat menghubungi para alumni sekolah yang dipimpinnya, di mana pun mereka berada. Alumni sukses yang dihubungi kerap tidak sungkan menyumbangkan dana untuk membangun almamaternya. Inilah berbagai sumber keuangan Haji Ajat dalam membangun sekolah yang dipimpinnya. Tentu saja, uang pribadi amat sangat sering digunakan untuk membangun aneka kebutuhan sekolah (wawancara dengan Responden F, 12/7/2013).

Analisis. Kesaksian sejumlah mantan Wakil Kepala Sekolah, yang mendampingi Haji Ajat, atau nama lengkapnya Drs. H. (Doktorandus Haji) Ajat Sudrajat, M.M.Pd. (Magister Manajemen Pendidikan) sebagai Kepala Sekolah, dapat menggambarkan bagaimana efektivitas education leadership yang dilakukan oleh Haji Ajat. Di samping itu, kesaksian mereka menjadi bukti bahwa Haji Ajat merupakan Kepala Sekolah dan 
Guru yang berkarakter kuat (Lickona, 1991; Zamroni, 2011; Sutikno, 2015; dan wawancara dengan Responden E, 11/7/2013).

Nunung Nurhayani, S.Pd. (Sarjana Pendidikan), Guru Matematika di SMAN (Sekolah Menengah Atas Negeri) Cilimus, Kuningan, Jawa Barat, misalnya, yang mendampingi Haji Ajat sebagai Wakil Kepala Sekolah Bidang Sarana, menuturkan dalam dua kesempatan wawancara yang berbeda bahwa Haji Ajat merupakan pemimpin dengan disiplin yang sangat tinggi. Lebih lanjut, Nunung Nurhayani, S.Pd. menyatakan, sebagai berikut:

Ia adalah pekerja keras yang tidak pernah menghitung perbandingan antara waktu kerja dengan gaji yang diterima. Bekerja ya bekerja, total. Sepanjang membantu Haji Ajat memimpin SMAN Cilimus, saya tidak bekerja santai. Semua terus berjalan, mengalir, bahkan lari dan terus berlari, seperti tidak pernah berhenti. Tentu saja banyak masalah yang dihadapi. Tapi masalah tak berhenti sebagai masalah, sebab bagi Haji Ajat, masalah harus dipecahkan. Pola belajar "problem solving" seperti inilah yang selalu dibelajarkan Haji Ajat kepada warga sekolah di SMA Negeri Cilimus (wawancara dengan Responden G, 27/7/2013).

Sebagai wanita, Haji Ajat memperlakukan saya secara proporsional. Bersikap baik dan ramah terhadap keluarga saya. Tapi sebagai Kepala Sekolah, Haji Ajat tetap terus memotivasi saya untuk bekerja maksimal. Saya merasa keteteran ketika harus menyesuaikan diri dengan irama kerja atasan saya. Sebab, larinya cepat sekali. Saya juga merasa seperti tidak akan mampu mengerjakannya. Sepertinya saya akan menyerah. Tapi Haji Ajat mempercayai saya, meminta saya mengerjakannya, dan terus dikerjakan. Subhanallah, ternyata, saya mampu mengerjakannya, dan selesai dengan baik. Pola dan irama kerja yang dituntut Haji Ajat itulah, yang akhirnya menjadi etos kerja saya (wawancara dengan Responden $\mathrm{G}$, 22/3/2017).

Pola kerja berlari seperti itu ternyata tidak hanya diajarkan kepada Nunung Nurhayani,
S.Pd. (Sarjana Pendidikan), tapi juga kepada Wakil Kepala Sekolah dan warga SMAN (Sekolah Menengah Atas Negeri) Cilimus, Kuningan, Jawa Barat, yang lain. Maka, pola kerja berlari menjadi ciri khas SMAN Cilimus. Lari, terus berlari, dan semua terus berlari. Dengan perubahan kultur kerja, maka SMAN Cilimus pun berubah. Tingkat kedisiplinan melonjak. Tapi warganya ramah, semua saling menyapa, saling memberi salam, saling menghormati, dan akhirnya saling bekerja sama (Mulyasa, 2007; Sutikno, 2015; wawancara dengan Responden H, 27/7/2013; dan wawancara dengan Responden I, 22/3/2017).

Yoyo Sofyan, S.Pd., yang saat itu menjadi Wakil Kepala SMAN 1 Luragung Bidang Sarana dan Prasarana, saat diwawancara pada tanggal 23 Maret 2017, juga menjelaskan bahwa selama Haji Ajat, nama lengkapnya Drs. H. (Doktorandus Haji) Ajat Sudrajat, M.M.Pd. (Magister Manajemen Pendidikan), memimpin SMAN Luragung, dirinya mendapat banyak sekali pengalaman, dari yang biasa menjadi luar biasa. Intinya, dengan mengelola sekolah secara profesional, maka sekolah dan warga sekolah terangkat kewibawaannya. Yang sangat luar biasa, Haji Ajat saat memimpin rapat mampu mempengaruhi yang lain secara positif. Di tangan Haji Ajat, hal yang mustahil pun jadi mungkin (Prihatni, 2011; Suhartini, 2015; dan wawancara dengan Responden J, 23/3/2017). Lebih lanjut, Yoyo Sofyan, S.Pd. menyatakan sebagai berikut:

Sampai sekarang, saya selalu terkesan dengan semboyan Haji Ajat tentang konsep 3P (Penampilan, Pelayanan, dan Prestasi). Penampilan yang baik, katanya, mampu melahirkan wibawa. Sementara pelayanan harus dilakukan di semua hal, terutama kepada siswa dan peserta didik, apalagi kepada tamu. Saat ada tamu datang, siapa pun tamu tersebut harus betul-betul mendapatkan pelayanan prima dan santun. Dengan penampilan lahir dan batin yang baik, disertai dengan pelayanan prima, maka dengan sendirinya warga sekolah, baik secara 
individu maupun kelembagaan, dapat meraih prestasi.

Karena kewibawaan dan kearifannya, semua orang bersedia mendengarkan dan menaati perintah Haji Ajat dari mana pun mereka berasal. Anak buah Haji Ajat tidak bisa bekerja asal-asalan. Semua bekerja serius dengan usaha yang maksimal. Apa pun hasilnya, yang penting telah melakukan upaya sebaik yang bisa dilakukan. Dengan demikian, selain dari hasil, bekerja bisa juga dilihat dari prosesnya (wawancara dengan Responden J, 23/3/2017).

Wakil Kepala SMAN (Sekolah Menengah Atas Negeri) 1 Bidang Kesiswaan di Luragung, Kuningan, Jawa Barat, Iwan Hernawan, M.Pd. (Magister Pendidikan), yang mendampingi Haji Ajat, atau nama lengkapnya Drs. $\mathrm{H}$. (Doktorandus Haji) Ajat Sudrajat, M.M.Pd. (Magister Manajemen Pendidikan), saat itu menceritakan bahwa Haji Ajat saat pertama datang ke SMAN 1 Luragung, pukul 03.00 WIB (Waktu Indonesia Barat). Begitu tiba, ia berjalan mengelilingi lingkungan sekolah untuk memotret keadaan sekolah. Saat mendampingi Haji Ajat itulah, menurut Iwan Hernawan, M.Pd., beliau mengatakan bahwa, "Kita harus berlari agar sekolah ini maju", sembari menambahkan bahwa dirinya saat itu belum tahu kredibilitas Haji Ajat (wawancara dengan Responden K, 24/3/2017). Lebih lanjut, Iwan Hernawan, M.Pd. menyatakan sebagai berikut:

Haji Ajat kemudian bertanya mengapa jumlah siswa SMA Luragung terus turun. Saya pun menjawab bahwa hal itu disebabkan adanya pesaing, dengan berdirinya SMK (Sekolah Menengah Kejuruan) yang baru. Karena ada SMK, jumlah siswa terbagi dua. Ternyata, jawaban ini tidak mampu memuaskan Haji Ajat. Persaingan bukanlah alasan. Yang paling tepat adalah, kata Haji Ajat, karena SMA Luragung tidak menyebabkan siswa merasa nyaman (wawancara dengan Responden K, 24/3/2017).

Iwan Hernawan, M.Pd. pun mengakui bahwa SMAN (Sekolah Menengah
Atas Negeri) 1 Luragung memang tidak nyaman. Itulah sebabnya, ketika Bupati Kuningan, Haji Aang Hamid Sugandha, melakukan kunjungan mendadak ke sekolah itu, beliau menyebut bahwa SMAN 1 Luragung sebagai "sekolah terkumuh" di Kuningan, Jawa Barat (Sumarno, 2015b; dan wawancara dengan Responden K, 24/3/2017). Kaitannya dengan Haji Ajat, Iwan Hermawan, M.Pd., kemudian, menyatakan sebagai berikut:

Karena itulah, Haji Ajat ditempatkan di SMAN 1 Luragung, Kuningan. Beliau mengajak untuk bersama-sama membangun sekolah ini. Insya Allah tahun ajaran baru, kata Haji Ajat, kita mampu menerima siswa baru 10 kelas. Mendengar pernyataan tersebut, saya sempat terperanjat. Sebab, kenyataan saat itu menunjukan bahwa jumlah peserta didik baru terus mengalami penurunan, dari semula 6 kelas, susut menjadi 5 kelas, dan terakhir tinggal 4 kelas.

Ternyata gebrakan Haji Ajat memang luar biasa. SMAN 1 Luragung memang dapat digambarkan seperti seekor burung yang sayapnya patah. Jangankan terbang, bahkan berjalan pun tidak mampu. Tapi tiba-tiba, datang seorang dokter, berwujud Haji Ajat, yang kemudian merawat, dan sangat telaten melatih. Setelah sehat, burung tersebut ternyata bisa terbang kembali. Itulah gambaran SMAN 1 Luragung (wawancara dengan Responden K, 24/3/2017).

Memimpin sekolah terlama, yang dijalani oleh Haji Ajat, atau nama lengkapnya Drs. H. (Doktorandus Haji) Ajat Sudrajat, M.M.Pd. (Magister Manajemen Pendidikan), adalah saat beliau menjadi Kepala Sekolah SMAN (Sekolah Menengah Atas Negeri) III Kuningan, Jawa Barat, Indonesia, dari tahun 2013 sampai dengan beliau pensiun pada bulan September 2017, yakni selama empat tahun. Menjadi Kepala Sekolah di tempat lain relatif lebih pendek. Karena relatif lama menjadi Kepala Sekolah di SMAN III Kuningan, Haji Ajat mampu menuntaskan hampir seluruh imaginasinya. Dengan seluruh kemampuan yang dimiliki, ia berhasil memobilisasi SDM (Sumber 
Daya Manusia) yang dimiliki SMAN III Kuningan. Bagaimana hasilnya? Dahsyat. Sekolah yang berada di seberang Kantor Kabupaten Kuningan, Jawa Barat tersebut tak ubahnya seperti hotel bintang lima (Dhama, 2015; Sundiawan, 2016a dan 2016b; dan wawancara dengan Responden L, 25/3/2017).

Berikut adalah kesaksian dan pernyataan dari para mantan Wakil Kepala Sekolah tentang pribadi dan prestasi Haji Ajat dalam memimpin sekolah di SMAN III Kuningan, Jawa Barat:

$$
\begin{aligned}
& \text { Ya, setaraf hotel termewah. Sebab, begitu } \\
& \text { memasuki pintu gerbang sekolah, udara } \\
& \text { terasa sejuk, padahal tidak ber-AC. } \\
& \text { Sementara, lingkungan sekitar terasa panas. } \\
& \text { Apalagi Stadion Mashud Wisnusaputra, } \\
& \text { yang jaraknya sekitar } 50 \text { meter di seberang } \\
& \text { SMAN III Kuningan, begitu menyengat. } \\
& \text { Mengapa sekolah terasa dingin? Karena } \\
& \text { seluruh sudut sekolah dipenuhi dengan aneka } \\
& \text { tanaman. Dari mulai tembok keliling sampai } \\
& \text { setiap sudut sekolah tidak ada satu pun yang } \\
& \text { terlewat dari tanaman, sehingga terlihat } \\
& \text { hijau (wawancara dengan Responden M, } \\
& \text { 26/3/2017). } \\
& \text { Di antara tetumbuhan di pelataran sekolah } \\
& \text { terdapat kolam ikan dengan air yang mengalir } \\
& \text { deras sepanjang 24 jam. Siapa pun yang } \\
& \text { masuk ke dalam sekolah terasa nyaman. } \\
& \text { Saking nyamannya suasana sekolah, siswa } \\
& \text { kerap malas pulang, walaupun sudah pukul } \\
& \text { 17.00 WIB. Padahal, sejak diberlakukan sistem } \\
& \text { "full day school", belajar berakhir adalah } \\
& \text { pukul 16.00 WIB. Apalagi halaman sekolah } \\
& \text { dilengkapi bangku yang bisa digunakan } \\
& \text { untuk duduk-duduk dan beristirahat, atau } \\
& \text { sekadar janjian bertemu antara teman yang } \\
& \text { satu dengan yang lain (wawancara dengan } \\
& \text { Responden N, 27/3/2017). }
\end{aligned}
$$

Setelah dipimpin oleh Haji Ajat, atau nama lengkapnya Drs. H. (Doktorandus Haji) Ajat Sudrajat, M.M.Pd. (Magister Manajemen Pendidikan), SMAN (Sekolah Menengah Atas Negeri) 3 Kuningan, Jawa Barat, Indonesia kemudian meraih penghargaan sebagai Sekolah Adiwiyata Mandiri pada tahun 2017. Piala ini merupakan penghargaan tertinggi di bidang pelestarian lingkungan hidup. Adiwiyata artinya tempat yang baik dan ideal untuk memperoleh ilmu pengetahuan dan berbagai norma serta etika yang dapat menjadi dasar manusia menuju terciptanya kesejahteraan hidup dan menuju cita-cita pembangunan berkelanjutan. Tujuan program Adiwiyata adalah mewujudkan warga sekolah yang bertanggung jawab dalam upaya melindungi dan mengelola lingkungan hidup melalui tata kelola sekolah yang baik untuk mendukung pembangunan berkelanjutan ( $c f$ KLH, 2012; Ahmad, 2017; Morgan, 2017; dan wawancara dengan Responden L, 25/3/2017).

\section{KESIMPULAN}

Haji Ajat, atau nama lengkapnya adalah Drs. H. (Doktorandus Haji) Ajat Sudrajat, M.M.Pd. (Magister Manajemen Pendidikan), merupakan pemimpin di dunia pendidikan, baik sebagai Guru maupun Kepala Sekolah yang berhasil. Selama sekitar 20 tahun memimpin 5 SMA (Sekolah Menengah Atas), sekolah-sekolah tersebut selalu meraih prestasi terbaik di tingkat regional, bahkan nasional. Selain pembangunan fisik yang sangat maju, sehingga sekolah yang dipimpinnya mirip dengan hotel bintang lima, kemajuan akademiknya juga sangat tinggi, sehingga berubah menjadi sekolah favorit di daerah. Perilakunya yang sangat religius menyebabkan ia menjadi pribadi yang bersih, disegani, dan menjadi pemimpin yang efektif.

Nama Haji Ajat seperti legenda dalam sejarah SMA di Kabupaten Kuningan, Jawa Barat, Indonesia. Sebab sepanjang menjadi Kepala Sekolah, sekolah yang dipimpinnya selalu menjadi yang terbaik. Tidak hanya di tingkat Kabupaten Kuningan dan Provinsi Jawa Barat, tapi juga pada tingkat nasional. Menjelang pensiun pada bulan Juli 2017, Haji Ajat sempat meraih penghargaan Sekolah Adiwiyata Mandiri, pada tahun 2017, untuk SMA Negeri III Kuningan yang dipimpinnya. 
Haji Ajat sendiri masuk dalam nomine sebagai peraih Kalpataru 2017. Bagaimana tidak, dalam kurun 20 tahun tersebut, Haji Ajat selalu ditugaskan menjadi Kepala Sekolah di SMA yang jauh dari perkotaan. Bahkan dapat dikatakan SMA pinggiran. Pada mulanya, ia ditugaskan memimpin SMA Negeri Ciniru, sekolah yang jaraknya memerlukan satu jam perjalanan dari Kuningan Kota, melalui jalan yang sulit dan jelek. Berkat "tangannya yang dingin", SMA Negeri Ciniru menjadi sekolah yang bernyali. Dengan melakukan rehab fisik secara besar-besaran dan menembok keliling area sekolah, SMA Negeri Ciniru menjadi berwibawa. Dengan membangun lapangan basket berstandar nasional, para siswa sangat bersemangat berolahraga. Maka, di mana pun ada pertandingan basket, SMA Negeri Ciniru lah pemenangnya. Secara psikologis, kemenangan demi kemenangan dapat mendorong prestasi akademik siswa SMA Negeri Ciniru. ${ }^{2}$

Selesai membangun jiwa dan raga SMA Negeri Ciniru, Haji Ajat berpindah ke SMA Negeri Mandirancan di Kuningan, Jawa Barat, Indonesia. Sekolah tersebut berada di tengah sawah dan di daerah pinggiran. Pembangunan fisik bangunan dan lapangan olahraga dijadikan sebagai alat pemicu keluarga besar SMA Negeri Mandirancan untuk maju dan berkembang. Dipimpin oleh Haji Ajat, SMA Negeri Mendirancan meraih penghargaan nasional bidang lingkungan hidup.

Sukses di Mandirancan, Haji Ajat berpindah memimpin SMA Negeri di dekat Kota Kuningan, tepatnya di SMA Negeri Cilimus, di kawasan wisata Sangkanhurip. Meskipun di tengah kawasan wisata, tapi lingkungan sekolah sangat kumuh. Tapi

\footnotetext{
${ }^{2}$ Lihat kembali, misalnya, "Drs. H. Sudrajat, M.M.Pd. Nominasi Kategori Pembina Lingkungan" dalam KALPATARU. Jakarta: 22 Juni 2016. Tersedia secara online juga di: https://kalpataru2016.wordpress.com/2016/06/22/ d-02-drs-h-sudrajat-m-m-pd-nominasi-kategori-pembinalingkungan [diakses di Purwokerto, Jawa Tengah, Indonesia: 27 Desember 2017].
}

lagi-lagi, SMA yang dipimpinnya tiba-tiba berubah menjadi indah, rapih, warga sekolah menjadi disiplin, semangat tinggi, prestasi akademiknya melonjak, serta tentu saja religius.

Berhasil memimpin SMA Negeri Cilimus, Haji Ajat berpindah memimpin SMA Negeri Luragung, sekitar perjalanan satu jam ke arah Jawa Tengah dari Kuningan, Jawa Barat. Sesuai standar Haji Ajat, SMA yang menempati 14 hektare ini disulap menjadi sekolah besar yang sangat berwibawa. Jumlah siswa yang terus menurun, tiba-tiba melonjak. Olahraga dan kesenian dijadikan sebagai daya tarik siswa untuk bersemangat membangun masa depan mereka. Grup sepak bolanya menjadi jawara di semua SMA Kuningan di Jawa Barat. Grup musiknya menjadi terkenal, sehingga saban hari Minggu pentas di Car Free Day di Kuningan, Jawa Barat. Pembangunan fisik sekolah dan lingkungan hidup tentang selalu menjadi andalannya.

Terakhir, Haji Ajat memimpin SMA Negeri III Kuningan yang berada di tengah kota Kuningan, dekat dengan GOR (Gelanggang Olah Raga) Mashud Wisnusaputra. Dengan kepiawaiannya, SMA Negeri III Kuningan berubah menjadi seperti hotel bintang lima. Suasana sejuk tanpa AC (Air Conditioner), indah, dan bersih. Semua sekolah yang dipimpinnya selalu dipel saban hari, minimal tiga kali, di hari libur sekalipun. Jangan tanya prestasi akademik, SMA Negeri III Kuningan langsung melonjak sebagai sekolah favorit pertama, sejak dipimpin oleh Haji Ajat.

Kepemimpinan sekolah (school leadership) yang berkarakter inilah yang perlu menjadi teladan bagi siapa pun, yang ingin berhasil memimpin sekolah. Tidak hanya SMA, tapi juga kepala sekolah di tingkat TK (Taman Kanak-kanak), SD (Sekolah Dasar), SMP (Sekolah Menengah Pertama), SMK (Sekolah Menengah Kejuruan), bahkan PT (Perguruan Tinggi). Menjadi pemimpin terbaik berarti 
menjadi pemimpin yang berkarakter. Pada kenyataannya, keberhasilan Haji Ajat memimpin SMA di Kabupaten Kuningan, Jawa Barat, Indonesia, karena dirinya melaksanakan semua karakter yang baik. Dengan demikian, dapat dikatakan bahwa Haji Ajat adalah pemimpin yang berkarakter kuat. $^{3}$

\section{Referensi}

Adiwikarta, S. (1988). Sosiologi Pendidikan: Isyu dan Hipotesis tentang Hubungan Pendidikan dengan Masyarakat. Jakarta: PPLPTK Dirjen Dikti, Depdikbud RI.

Ahmad, Victor Imaduddin. (2017). "Manajemen Sistem Lingkungan Sekolah Adiwiyata Mandiri: Studi Kasus di SMA Negeri I Lamongan" dalam KUTTAB, Vo.1, No.1 [Maret]. Tersedia secara online juga di: http://docplayer.info/48718543Manajemen-sistem-lingkungan-sekolahadiwiyata-mandiri-studi-kasus-di-sma-negerii-lamongan.html [diakses di Purwokerto, Jawa Tengah, Indonesia: 2 Maret 2018].

Andriansyah. (2015). Kepemimpinan Visioner Kepala Daerah. Jakarta: Fakultas Ilmu Sosial dan Ilmu Politik Universitas Prof. Dr. Moestopo Beragama. Tersedia secara online juga di: https:// moestopo.ac.id/wp-content/uploads/2016/05/ Kepemimpinan-Visioner-Kepala-Daerah [diakses di Purwokerto, Jawa Tengah, Indonesia: 27 Desember 2017].

Asmani, Ma'mur Jamal. (2012). Tips Menjadi Kepala Sekolah Profesional. Jogjakarta: Diva Press.

Bahri, Ahmad Syaiful. (2015). "Kuningan Menuju Kabupaten Pendidikan" dalam Web Resmi Kabupaten Kuningan: Rapih Winangun Kerta Raharya. Kuningan: 14 September. Tersedia secara online juga di: https://www.kuningankab. go.id/berita/kuningan-menuju-kabupatenpendidikan [diakses di Purwokerto, Jawa Tengah, Indonesia: 10 November 2017].

\footnotetext{
${ }^{3}$ Pernyataan: Saya, dengan ini, menyatakan bahwa artikel ini, beserta seluruh isinya, adalah benar-benar karya saya sendiri, dan saya tidak melakukan penjiplakan atau pengutipan dengan cara yang tidak sesuai dengan etika keilmuan yang berlaku dalam masyarakat akademik. Atas pernyataan ini, saya siap menanggung risiko/sanksi yang dijatuhkan kepada saya apabila kemudian ditemukan adanya pelanggaran terhadap etika keilmuan dalam karya saya ini, atau ada klaim dari pihak lain terhadap keasliaan karya saya ini.
}

Berlian, Zainal. (2012). "Penerapan Model Kepemimpinan Transformasional dalam Dunia Pendidikan" dalam TA'DIB, Vol.XVII, No.02 [Desember]. Tersedia secara online juga di: http://download.portalgaruda.org/article. php?article $=318146$ [diakses di Purwokerto, Jawa Tengah, Indonesia: 27 Desember 2017].

Creswell, J.W. (1998). Qualitatvie Inquiry and Research Design: Choosing among Five Traditions. USA [United State of America]: Sage Publications.

Danim, Sudarman. (2010). Kepemimpinan Pendidikan. Bandung: Alfabeta.

Dhama, Atik. (2015). "Prestasi Siswa dalam Olimpiade Sains Kabupaten Kuningan Tahun 2015" dalam SMA Negeri 3 Kuningan: Media Informasi dan Komunikasi Warga Sekolah. Kuningan: 23 Februari. Tersedia secara online juga di: http://www.sman3kuningan.sch.id [diakses di Purwokerto, Jawa Tengah, Indonesia: 27 Desember 2017].

"Drs. H. Sudrajat, M.M.Pd. Nominasi Kategori Pembina Lingkungan" dalam KALPATARU. Jakarta: 22 Juni 2016. Tersedia secara online juga di: https://kalpataru2016.wordpress. com/2016/06/22/d-02-drs-h-sudrajat-m-m-pdnominasi-kategori-pembina-lingkungan [diakses di Purwokerto, Jawa Tengah, Indonesia: 27 Desember 2017].

Edberg, Henrik. (2010). "Helen Keller's Guide to Courageously Looking the World Staright in the Eye". Tersedia secara online di: https:// www.positivityblog.com/helen-keller/ [diakses di Purwokerto, Jawa Tengah, Indonesia: 10 November 2017].

Eko, I.F. (2018). "Teori Kepemimpinan". Tersedia secara online di: http://ekoif.weebly.com/teorikepemimpinan.html [diakses di Purwokerto, Jawa Tengah, Indonesia: 3 Juli 2018].

Gunawan, Ary H. (2000). Sosiologi Pendidikan: Suatu Analisis Sosiologi tentang Pelbagai Problem Pendidikan. Jakarta: PT Renika Cipta.

Haris, Abd. (2013). Kepemimpinan Pendidikan: Buku Perkuliahan, Paket 1 s.d. 12. Jakarta: GoI [Government of Indonesia] and IDB [Islamic Development Bank].

Hasanah, Hasyim. (2016). "Teknik-teknik Observasi: Sebuah Alternatif Metode Pengumpulan Data Kualitatif Ilmu-ilmu Sosial" dalam Jurnal atTaqaddum, Vol.8, No.1 [Juli], hlm.21-46.

Hermawan, Iwan. (2012). "Kearifan Lokal Sunda dalam Pendidikan" dalam Widyariset, Vol.15, No.1 [April]. Tersedia secara online juga di: http://download.portalgaruda.org/article. php?article $=351253$ [diakses di Purwokerto, Jawa Tengah, Indonesia: 10 November 2017]. 
Holmes, Brian. (2002). "Herbert Spencer, 18201903" in PROSPECTS: The Quarterly Review of Comparative Education, Vol.24, No.3/4, pp.533-554. Available online also at: http://www. ibe.unesco.org/sites/default/files/spencere.pdf [diakses di Purwokerto, Jawa Tengah, Indonesia: 10 November 2017].

Iqbal, Muchammad. (2014). “Konsep

Neomodernisme dan Implikasinya dalam Pendidikan Islam: Studi Paradigmatik Pemikiran Fazlur Rahman”. Skripsi Sarjana Tidak Diterbitkan. Malang: Jurusan Pendidikan Agama Islam UIN [Universitas Islam Negeri] Maulana Malik Ibrahim. Tersedia secara online juga di: http://etheses.uin-malang.ac.id/8928/1/09110169. pdf [diakses di Purwokerto, Jawa Tengah, Indonesia: 10 November 2017].

Isnaeni, Hendri F. (2015). "Sebelum Tobat, Sunan Kalijaga Pernah Jadi Begal: Sunan Kalijaga Semasa Muda Menjadi Begal, Setelah Tobat Menjadi Wali Penyebar Agama Islam" dalam HISTORIA: Masa Lampau Selalu Aktual, Edisi 28 Maret. Tersedia secara online juga di: https:/historia.id/agama/articles/sebelumtobat-sunan-kalijaga-pernah-jadi-begal [diakses di Purwokerto, Jawa Tengah, Indonesia: 27 Desember 2017].

Jalal, Fasli \& Dedi Supriadi [eds]. (2001). Reformasi Pendidikan dalam Konteks Otonomi Daerah. Yogyakarta: Adi Cita.

Karwati, E. et al. (2013). Kinerjadan Profesionalisme Kepala Sekolah. Bandung: Alfabeta.

KLH [Kementrian Lingkungan Hidup]. (2012). "Informasi Mengenai Adiwiyata". Tersedia secara online di: http://www.menlh.go.id/ informasimengenai-adiwiyata [diakses di Purwokerto, Jawa Tengah, Indonesia: 27 Desember 2017].

Lickona, T. (1991). Educating for Character: How Our Schools Can Teach Respect and Responsibility. New York: Bantam Books.

Lincoln, Y.S. \& E.G. Guba. (1985). Naturalistic Inquiry. USA [United State of America]: Sage Publication.

Luno. (2016). “Abraham Lincoln: Political Philospohy”. Tersedia secara online di: https:// www.quora.com/Abraham-Lincoln-said-Nearlyall-men-can-stand-the-test-of-adversity [diakses di Purwokerto, Jawa Tengah, Indonesia: 10 November 2017].

Margana, Bondhan. (2001). Wayang Purwa beserta Penjelasannya. Surakarta: Cendrawasih.

Moleong, L.J. (2004). Metodologi Penelitian Kualitatif. Bandung: PT Remaja Rosdakarya.

Morgan, Raymond Agasi. (2017). "Sekolah Menengah Atas Negeri dengan Program
Adiwiyata di Kabupaten Gunung Kidul, Daerah Istimewa Yogyakarta". Tersedia secara online di: http://e-journal.uajy.ac.id/11424/1/Jurnal\%20 TA14268.pdf [diakses di Purwokerto, Jawa Tengah, Indonesia: 2 Maret 2018].

Mu'in, Fatchul. (2011). Pendidikan Karakter: Konstruksi Teoretis \& Praktik. Yogyakarta: ArRuzz Media.

Mulyadi. (2010). Kepemimpinan Kepala Sekolah dalam Mengembangkan Budya Mutu. Malang: UIN [Universitas Islam Negeri] Maulana Maliki Ibrahim Press.

Mulyadi, Taufiq Arif. (2013). "Usaha Kepala Sekolah dalam Meningkatkan Proses Pembelajaran AlQur'an di SMK Ma'arif Sleman, Yogyakarta”. Skripsi Sarjana Tidak Diterbitkan. Yogyakarta: Jurusan Pendidikan Agama Islam UIN [Universitas Islam Negeri] Sunan Kalijaga. Tersesia secara online juga di: http://digilib.uinsuka.ac.id/9228/2 [diakses di Purwokerto, Jawa Tengah, Indonesia: 10 November 2017].

Mulyasa, E. (2007). Menjadi Kepala Sekolah Profesional. Bandung: Remaja Rosda Karya.

Mulyono, Sri. (1989). Simbolisme dan Mistikisme dalam Wayang. Jakarta: Haji Masagung.

Mustakim, Bagus. (2011). Pendidikan Karakter: Membangun Delapan Belas Karakter Emas Manusia Indonesia Bermartabat. Yogyakarta: Samudera Biru.

Noer, Muhammad. (2018). Essential Skills for New Manager, Seri 1: Mengelola Tim. Jakarta: Presenta, Terjemahan.

Prihatni, D. (2011). "Pengaruh Perilaku Kepemimpinan Kepala Sekolah dan Kepuasan Kerja Guru terhadap Mutu Sekolah” dalam Jurnal Manajerial, Vol.10, No.1. Tersedia secara online juga di: www.ejournal.upi.edu/index.php/ manajerial/article/download/2169/15 [diakses di Purwokerto, Jawa Tengah, Indonesia: 27 Desember 2017].

Rachbini, Didik J. (2017). "Paradoks Pendidikan dan Dunia Kerja" dalam Detik News. Jakarta: 10 Januari. Tersedia secara online juga di: https://news.detik. com/kolom/3392366/paradoks-pendidikan-dandunia-kerja [diakses di Purwokerto, Jawa Tengah, Indonesia: 2 Maret 2018].

Raharjo, Sabar Budi. (2016). "Manajemen Sekolah untuk Mencapai Sekolah Unggul yang Menyenangkan: Studi Kasus di SMAN 1 Sleman, Yogyakarta" dalam Jurnal Pendidikan dan Kebudayaan, Vol.1, No.2 [Agustus]. Tersedia secara online juga di: https://media. neliti.com/media/publications/119716-IDmanajemen-sekolah-untuk-mencapai-sekolah. pdf [diakses di Purwokerto, Jawa Tengah, Indonesia: 2 Maret 2018]. 
Rizal, A. Syamsu et al. (2016). "Membangun Karakter Kemanusiaan, Membentuk Kepribadian Bangsa Melalui Pendidikan". Bahan Perkuliahan Belum Diterbitkan. Banjarmasin: UPT MKU [Unit Pelaksana Teknis, Mata Kuliah Umum] Universitas Lambung Mangkurat.

Rohiat. (2008). Kecerdasan Emosional: Kepemimpinan Kepala Sekolah. Bandung: Refika Aditama.

Rusdiana, H.A. (2014). Konsep Inovasi Pendidikan. Bandung: Pustaka Setia. Tersedia secara online juga di: http://digilib.uinsgd.ac.id/8787/1/Buku [diakses di Purwokerto, Jawa Tengah, Indonesia: 27 Desember 2017].

Safari, Daud. (2013). “Antara Biografi dan Historiografi: Studi 36 Buku Biografi di Indonesia" dalam Analisis, Vol.XIII, No.1 [Juni].

Sahlan, Asmaun. (2010). Mewujudkan Budaya Religius di Sekolah. Malang: UIN [Universitas Islam Negeri] Maliki Press.

Saputra, Stef Riko. (2011). "Pengaruh Penerapan Model CTL (Contextual Teaching and Learning) dan Kemampuan Membaca Pemahaman terhadap Hasil Belajar Matematika Soal Cerita Siswa Kelas V SD Kecamatan Wonogiri, Tahun Pelajaran 2011/2012". Skripsi Sarjana Tidak Diterbitkan. Surakarta: FKIP UNS [Fakultas Keguruan dan Ilmu Pendidikan, Universitas Sebelas Maret.

Sinamo, Jansen. (2005). Delapan Etos Kerja Profesional: Navigator Anda Menuju Sukses. Bogor: Grafika Mardi Yuana, Terjemahan.

Siswoyo, Agus. (2016). "Cerita Rakyat Jawa Barat: Legenda Sangkuriang, Dayang Sumbi, dan Asal-Usul Gunung Tangkuban Parahu”. Tersedia secara online di: http://agussiswoyo. com/sejarah-nusantara/cerita-rakyat-jawabarat-legenda-sangkuriang-dayang-sumbi-danasal-usul-gunung-tangkuban-parahu [diakses di Purwokerto, Jawa Tengah, Indonesia: 10 November 2017].

Spradley, James P. (1980). The Ethnographic Interview. New York: Holt Renehart and Winston.

Suhartini, Cucu. (2015). "Pengaruh Kepemimpinan Kepala Sekolah dan Budaya Sekolah terhadap Komitmen Profesi Guru, serta Implikasinya terhadap Kinerja Guru: Survey pada Guru Ekonomi SMA Negeri di Kabupaten Kuningan”. Tersedia secara online di: http://download. portalgaruda.org/article.php? article $=340005$ [diakses di Purwokerto, Jawa Tengah, Indonesia: 10 November 2017].

Sulaeman, Mubaidi. (2018). "Urgensi Manajemen Peningkatan Mutu Berbasis Sekolah di Lembaga Pendidikan Islam" dalam Realita, Vol.16, No.1.

Sulasih. (2014). “Analisis Pemikiran Tokoh Pendidikan Islam”. Tersedia secara online di:
https://www.academia.edu/9791192/ANALISIS PEMIKIRAN_TOKOH_PENDIDIKAN_ISLAM [diakses di Purwokerto, Jawa Tengah, Indonesia: 10 November 2017].

Sumarno. (2015a). "Drs. H. Sudrajat, M.M.Pd. Terpilih sebagai Ketua Forum Musyawarah Sekolah Berbudaya Lingkungan/Adiwiyata Kabupaten Kuningan" dalam SMA Negeri 3 Kuningan: Media Informasi dan Komunikasi Warga Sekolah. Kuningan: 13 Februari. Tersedia secara online juga di: http://www.sman3kuningan. sch.id [diakses di Purwokerto, Jawa Tengah, Indonesia: 27 Desember 2017].

Sumarno. (2015b). "Pengurus FMSBL/Adiwiyata Kabupaten Kuningan Silaturahmi ke Bupati Kuningan" dalam SMA Negeri 3 Kuningan: Media Informasi dan Komunikasi Warga Sekolah. Kuningan: 17 Maret. Tersedia secara online juga di: http://www.sman3kuningan.sch.id [diakses di Purwokerto, Jawa Tengah, Indonesia: 27 Desember 2017].

Sundiawan, Awan. (2016a). "BPLH Kabupaten Bandung Mengagumi SMAN 3 Kuningan sebagai Sekolah Adiwiyata Nasional/Sekolah Berbasis Lingkungan" dalam SMA Negeri 3 Kuningan: Media Informasi dan Komunikasi Warga Sekolah. Kuningan: 17 Maret. Tersedia secara online juga di: http://www.sman3kuningan.sch.id [diakses di Purwokerto, Jawa Tengah, Indonesia: 27 Desember 2017].

Sundiawan, Awan. (2016b). "SMAN 3 Kuningan Dijadikan Narasumber Adiwiyata oleh Kementerian Lingkungan Hidup dan Semakin Mantap sebagai Sekolah Adiwiyata Mandiri Nasional" dalam SMA Negeri 3 Kuningan: Media Informasi dan Komunikasi Warga Sekolah. Kuningan: 1 April. Tersedia secara online juga di: http://www.sman3kuningan.sch.id [diakses di Purwokerto, Jawa Tengah, Indonesia: 27 Desember 2017].

Sutikno, Untung. (2015). "Menjadi Kepala Sekolah Berkarakter dan Profesional" dalam KOMPASIANA: Byond Blogging. Jakarta: 14 Juni. Tersedia secara online juga di: https://www. kompasiana.com/untungsutikno/552 [diakses di Purwokerto, Jawa Tengah, Indonesia: 27 Desember 2017].

Syam, Aminuddin. (2012). "Kepemimpinan Pendidikan yang Inovatif' in Jurnal Al-Ta'lim, Jilid 1, Nomor 2 [Juli]. Padang: Fakultas Tarbiyah IAIN [Institut Agama Islam Negeri] Imam Bonjol.

Wahed, Abd. (2016). "Model Kepemimpinan Kepala Madrasah dan Permasalahannya" dalam Al-Ibrah, Vol.1, No.1 [Juni]. Tersedia secara online juga di: http://download.portalgaruda.org/article. php?article $=491902$ [diakses di Purwokerto, Jawa 
Tengah, Indonesia: 10 November 2017].

Wawancara dengan Responden A, mantan Wakil Kepala Sekolah Bidang Kurikulum di SMAN (Sekolah Menengah Atas Negeri) Ciniru, Kuningan, Jawa Barat, Indonesia. Wawancara dilakukan di Kuningan, Jawa Barat, Indonesia, pada tanggal 3 Juli 2013.

Wawancara dengan Responden B, mantan Wakil Kepala Sekolah Bidang Sarana dan Prasarana di SMAN (Sekolah Menengah Atas Negeri) Ciniru, Kuningan, Jawa Barat, Indonesia. Wawancara dilakukan di Kuningan, Jawa Barat, Indonesia, pada tanggal 4 Juli 2013.

Wawancara dengan Responden C, mantan Wakil Kepala Sekolah Bidang Kesiswaan di SMAN (Sekolah Menengah Atas Negeri) Ciniru, Kuningan, Jawa Barat, Indonesia. Wawancara dilakukan di Kuningan, Jawa Barat, Indonesia, pada tanggal 5 Juli 2013.

Wawancara dengan Responden D, mantan Wakil Kepala Sekolah Bidang Kurikulum di SMAN (Sekolah Menengah Atas Negeri) Mandirancan, Kuningan, Jawa Barat, Indonesia. Wawancara dilakukan di Kuningan, Jawa Barat, Indonesia, pada tanggal 10 Juli 2013.

Wawancara dengan Responden E, Haji Suleha atau Pak Uha, mantan Wakil Kepala Sekolah Bidang Sarana dan Prasarana di SMAN (Sekolah Menengah Atas Negeri) Mandirancan, Kuningan, Jawa Barat, Indonesia. Wawancara dilakukan di Kuningan, Jawa Barat, Indonesia, pada tanggal 11 Juli 2013.

Wawancara dengan Responden F, mantan Wakil Kepala Sekolah Bidang Kesiswaan di SMAN (Sekolah Menengah Atas Negeri) Mandirancan, Kuningan, Jawa Barat, Indonesia. Wawancara dilakukan di Kuningan, Jawa Barat, Indonesia, pada tanggal 12 Juli 2013.

Wawancara dengan Responden G, Nunung Nurhayani, S.Pd., Guru Matematika dan mantan Wakil Kepala Sekolah Bidang Sarana di SMAN (Sekolah Menengah Atas Negeri) Cilimus, Kuningan, Jawa Barat, Indonesia. Wawancara dilakukan di Kuningan, Jawa Barat, Indonesia, pada tanggal 27 Juli 2013 dan 22 Maret 2017.

Wawancara dengan Responden H, mantan Wakil Kepala Sekolah Bidang Kurikulum di SMAN (Sekolah Menengah Atas Negeri) Cilimus, Kuningan, Jawa Barat, Indonesia. Wawancara dilakukan di Kuningan, Jawa Barat, Indonesia, pada tanggal 27 Juli 2013.

Wawancara dengan Responden I, mantan Wakil Kepala Sekolah Bidang Kesiswaan di SMAN
(Sekolah Menengah Atas Negeri) Cilimus, Kuningan, Jawa Barat, Indonesia. Wawancara dilakukan di Kuningan, Jawa Barat, Indonesia, pada tanggal 22 Maret 2017.

Wawancara dengan Responden J, Yoyo Sofyan, S.Pd., mantan Wakil Kepala Sekolah Bidang Sarana dan Prasarana di SMAN (Sekolah Menengah Atas Negeri) Luragung, Kuningan, Jawa Barat, Indonesia. Wawancara dilakukan di Kuningan, Jawa Barat, Indonesia, pada tanggal 23 Maret 2017.

Wawancara dengan Responden K, Iwan Hernawan, M.Pd., mantan Wakil Kepala SMAN (Sekolah Menengah Atas Negeri) 1 Bidang Kesiswaan di Luragung, Kuningan, Jawa Barat, Indonesia. Wawancara dilakukan di Kuningan, Jawa Barat, Indonesia, pada tanggal 24 Maret 2017.

Wawancara dengan Responden L, mantan Wakil Kepala SMAN (Sekolah Menengah Atas Negeri) III Bidang Kurikulum di Kuningan, Jawa Barat, Indonesia. Wawancara dilakukan di Kuningan, Jawa Barat, Indonesia, pada tanggal 25 Maret 2017.

Wawancara dengan Responden M, mantan Wakil Kepala SMAN (Sekolah Menengah Atas Negeri) III Bidang Sarana dan Prasarana di Kuningan, Jawa Barat, Indonesia. Wawancara dilakukan di Kuningan, Jawa Barat, Indonesia, pada tanggal 26 Maret 2017.

Wawancara dengan Responden N, mantan Wakil Kepala SMAN (Sekolah Menengah Atas Negeri) III Bidang Kesiswaan di Kuningan, Jawa Barat, Indonesia. Wawancara dilakukan di Kuningan, Jawa Barat, Indonesia, pada tanggal 27 Maret 2017.

Widodo, S.E. (2011). Manajemen Mutu Pendidikan untuk Guru dan Kepala Sekolah. Jakarta: Ardadizya Jaya.

Yalia, Mulyono. (2014). “Kebijakan Pemerintah Daerah Kabupaten Kuningan dalam Pemanfaatan TIK bagi Pengembangan Kepariwisataan Daerah" dalam Jurnal Penelitian Komunikasi dan Opini Publik, Vol.18, No.3 [Desember], hlm.255-264. Tersedia secara online juga di: https://media. neliti.com/media/publications/123542-IDkebijakan-pemerintah-daerah-kabupaten-ku.pdf [diakses di Purwokerto, Jawa Tengah, Indonesia: 10 November 2017].

Yin, R.K. (2004). Studi Kasus: Desain dan Metode. Jakarta: PT Rajagrafindo Persada, terjemahan M. Djauzi Mudzakir.

Zamroni. (2011). Pendidikan Karakter dalam Pespektif Teori dan Praktik. Yogyakarta: UNY [Universitas Negeri Yogyakarta] Press. 